\title{
MyD88 Is Not Required for Muscle Injury-Induced Endochondral Heterotopic Ossification in a Mouse Model of Fibrodysplasia Ossificans Progressiva
}

\author{
Huili Lyu ${ }^{1,2}$, Cody M. Elkins ${ }^{1}$, Jessica L. Pierce ${ }^{1}$, C. Henrique Serezani ${ }^{3}$ and Daniel S. Perrien ${ }^{1, *}$ \\ 1 Division of Endocrinology, Metabolism, and Lipids, Department of Medicine, Emory University, \\ Atlanta, GA 30322, USA; huili.lyu@emory.edu (H.L.); cody.elkins@emory.edu (C.M.E.); \\ jessica.liane.pierce@emory.edu (J.L.P.) \\ 2 Department of Endocrinology, Endocrinology Research Center, \\ Xiangya Hospital of Central South University, Changsha 410000, China \\ 3 Division of Infectious Diseases, Department of Medicine, Vanderbilt University Medical Center, \\ Nashville, TN 37232, USA; h.serezan@vumc.org \\ * Correspondence: dperrie@emory.edu
}

check for updates

Citation: Lyu, H.; Elkins, C.M.; Pierce, J.L.; Serezani, C.H.; Perrien, D.S. MyD88 Is Not Required for Muscle Injury-Induced Endochondral Heterotopic Ossification in a Mouse Model of Fibrodysplasia Ossificans Progressiva. Biomedicines 2021, 9, 630 . https://doi.org/10.3390

/biomedicines 9060630

Academic Editor: Roberto Ravazzolo

Received: 3 May 2021

Accepted: 25 May 2021

Published: 1 June 2021

Publisher's Note: MDPI stays neutral with regard to jurisdictional claims in published maps and institutional affiliations.

Copyright: (c) 2021 by the authors. Licensee MDPI, Basel, Switzerland. This article is an open access article distributed under the terms and conditions of the Creative Commons Attribution (CC BY) license (https:/ / creativecommons.org/licenses/by/ $4.0 /)$.
Abstract: Excess inflammation and canonical BMP receptor (BMPR) signaling are coinciding hallmarks of the early stages of injury-induced endochondral heterotopic ossification (EHO), especially in the rare genetic disease fibrodysplasia ossificans progressiva (FOP). Multiple inflammatory signaling pathways can synergistically enhance BMP-induced Smad1/5/8 activity in multiple cell types, suggesting the importance of pathway crosstalk in EHO and FOP. Toll-like receptors (TLRs) and IL-1 receptors mediate many of the earliest injury-induced inflammatory signals largely via MyD88-dependent pathways. Thus, the hypothesis that MyD88-dependent signaling is required for $\mathrm{EHO}$ was tested in vitro and in vivo using global or Pdgfr $\alpha$-conditional deletion of MyD88 in FOP mice. As expected, IL-1 $\beta$ or LPS synergistically increased Activin A (ActA)-induced phosphorylation of Smad 1/5 in fibroadipoprogenitors (FAPs) expressing Alk2 ${ }^{\mathrm{R} 206 \mathrm{H}}$. However, conditional deletion of MyD88 in Pdgfr $\alpha$-positive cells of FOP mice did not significantly alter the amount of muscle injury-induced EHO. Even more surprisingly, injury-induced $\mathrm{EHO}$ was not significantly affected by global deletion of MyD88. These studies demonstrate that MyD88-dependent signaling is dispensable for injury-induced $\mathrm{EHO}$ in FOP mice.

Keywords: IL-1 $\beta$; muscle injury and repair; chondrogenesis; osteogenesis; Acvr1; fibroadipoprogenitor; FAP; MyD88

\section{Introduction}

Fibrodysplasia ossificans progressiva (FOP) is a rare congenital disease caused by one of several point mutations in the BMP type I receptor, ALK2 [1,2] and results in episodes of hyperinflammatory, fibroproliferative, and edematous soft tissue lesions, termed "flares", that frequently progress to intramuscular endochondral heterotopic ossification (EHO) [3-6]. Heterotopic ossification (HO) is a pathological process of extraskeletal osteogenesis in muscle and soft tissue. Over time, HO progressively replaces skeletal muscles, typically leading to joint ankylosis, disfigurement, pain, and loss of mobility $[3,5,7,8]$. In addition to FOP, EHO is also a common clinical complication of musculoskeletal trauma and other rare genetic diseases. Unfortunately, there are currently no approved effective treatments for FOP, and knowledge of the underlying mechanisms is very limited.

The most common FOP-causing mutation is $A C V R 1^{617 \mathrm{G}>\mathrm{A}}$, which encodes ALK2 ${ }^{\mathrm{R} 206 \mathrm{H}}[1]$. The expression of Alk2 ${ }^{\mathrm{R} 206 \mathrm{H}}$ in mesenchymal-like fibroadiprogenitors (FAPs) residing in skeletal muscle is necessary and sufficient for injury-induced EHO in mice $[9,10]$. While other potential progenitor cell linages have been described for both FOP and acquired heterotopic ossification [11-19], FAPs appear to be the primary chondrocyte progenitor 
in FOP lesions $[9,10,20]$. The $\mathrm{ALK} 2^{\mathrm{R} 206 \mathrm{H}}$ mutation causes hypersensitivity to its cognate osteogenic BMP ligands and, more importantly, confers neofunctional sensitivity to aberrant Activin A (ActA)-induced signaling [21,22]. A member of the TGF $\beta$ superfamily, ActA is the requisite ligand for EHO formation in FOP mice [10,21-23], and an anti-activin A antibody, garetosumab, is currently in clinical trials for the treatment of FOP. Despite these key discoveries, it is clear that many other cell types and signaling pathways contribute to the complex process of EHO in FOP.

$\mathrm{HO}$ has been described by some as a form of failed or misdirected tissue repair. Indeed, whether caused by musculoskeletal trauma, burns, or FOP, EHO almost uniformly begins with inflammation, and the depletion of mast cells or macrophages reduces intramuscular $\mathrm{EHO}$ in multiple mouse models [24-26], including $\mathrm{Alk} 2^{\mathrm{R} 206 \mathrm{H}_{-}}$-expressing FOP mice [25]. Consequently, the roles of inflammatory cytokines and related signaling pathways are of great interest in the field.

Although the underlying cause of FOP is inappropriate activation of the Smad1/5/8 pathway by ActA/ALK2 ${ }^{\mathrm{R} 206 \mathrm{H}}$ signaling, the kinetics and transcriptional effects of this aberrant signal may still be modulated by crosstalk with other pathways. Indeed, inflammatory cytokines and signaling pathways, including toll-like receptors (TLRs) and their ligands, can enhance BMP-induced Smad1/5/8 signaling in Alk2 ${ }^{\text {wt }}$ cells [27-30] and cells from FOP patients [31].

Toll-like receptors (TLRs) are a group of widely expressed transmembrane receptors activated by "debris" of damaged and necrotic cells and/or pathogens (pathogenassociated molecular patterns, PAMPs). The release of damage-associated molecular patterns (DAMPs) is one of the first consequences of cell and tissue damage. DAMPs, including CpG DNA fragments, S100A1, and ribosomal RNA, activate TLRs on neighboring cells and distant innate immune cells, leading to inflammatory immune cell activation and migration. DAMP-induced TLR signals are among the first inflammatory signals in damaged tissues, and TLR signaling has been shown to regulate ActA expression [32-35] and enhance canonical BMP signaling [31,36,37].

One study using patient-derived FOP fibroblasts reported that $\mathrm{TNF} \alpha$ increases the expression of TLRs 3-10, and TNF $\alpha$-induced expression of TLRs 1, 2, 3, 4, and 6 is significantly greater in FOP fibroblasts than in WT fibroblasts [31]. They also found the classical TLR4 agonist, LPS, and TLR3 agonist, polyIC, enhance BMP signaling at the level of type 1 receptor activity via the TLR signaling intermediate ECSIT [31], which is a downstream component of MyD88-dependent pathways activated by both TLRs and IL1 receptor 1 (IL1R1). The results of these studies suggest the adapter protein MyD88, which is required for most TLR- and IL1R1-induced signaling, may be important for interactions between TLR and canonical BMP signaling. However, crosstalk of these pathways has not been reported in the context of aberrant ActA/Alk $2^{\mathrm{R} 206 \mathrm{H}}$-induced signaling. Hence, the studies reported here were designed to test the hypothesis that MyD88-dependent signaling enhances ActA-induced signaling of Alk $2^{\mathrm{R} 206 \mathrm{H}}$ and is required for muscle injury-induced EHO in FOP mice. These studies utilized tamoxifen-induced ubiquitous or conditional deletion of MyD88 in Alk $2^{R 206 H}$-expressing mouse models of FOP to demonstrate that MyD88 is unexpectedly dispensable in the growth, maturation, and remodeling of EHO lesions.

\section{Materials and Methods}

\subsection{Animal Husbandry and Breeding}

All studies were approved by the Institutional Animal Care and Use Committee at Emory University (protocol 201900179, approved 4 November 2019) or Vanderbilt University Medical Center (protocol M1800121, Approved 8 October 2018) and followed ARRIVE guidelines. Mice were housed in standard cages with free access to food and water and a $13 \mathrm{~h}$ on/11 h off light schedule. Acvr1 ${ }^{\text {R206H_FlEx }}$ (VG1649) mice [22] were generously provided by Regeneron Pharmaceuticals, Inc. (Tarrytown, NY, USA) through a research agreement. Acvr $1^{R 206 H \_m g}$ mice were designed by this lab, created at Ozgene, Inc. (Perth, Australia), and are described in detail in another pending publication [38]. Myd88-floxed $\left(M y d 88^{f / f}\right)\left(B 6.129 P 2(S J L)-M y d 88^{t m 1 D e f r} / J\right.$, 


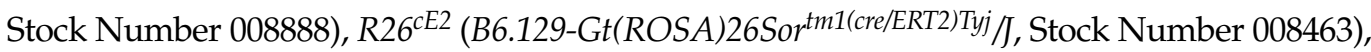
and Pdgfra ${ }^{c E 2}$ (B6.129S-Pdgfratm1.1(cre/ERT2)Blh/J, Stock Number 032770) mice were purchased from The Jackson Laboratory (Bar Harbor, ME, USA) and crossed with Acvr $1^{\text {R206H_FlEx/+ }}$ or Acvr1 ${ }^{R 206 H \_m g}$ mice to create the following lines: $R 26^{c E 2 / c E 2} ; A c v r 1^{R 206 H \_F l E x / w} ; M y d 88^{\text {ww/w }}$ and $R 26^{c E 2 / c E 2} ; A c v r 1^{R 206 H_{-} F l E x /+} ; M y d 88^{f / f}$ (respectively dubbed $A c v r 1^{R 206 H_{-} F l E x} ; M y d 88^{w / w}$ and Acvr1 ${ }^{R 206 H \_F l E x} ; M y d 88^{-/-}$after tamoxifen-induced recombination), Pdgfrac ${ }^{c E 2 / w}$; Acvr1 ${ }^{R 206 H \_F l E x / w} ; M y d 88^{w / w}$ and Pdgfra ${ }^{c E 2 / w} ; A c v r 1^{R 206 H \_F l E x / w} ; M y d 88^{f / f}$ (respectively dubbed Acvr1 ${ }^{R 206 H \_F l E x} ; M y d 88^{w / w}$ and Acvr1 ${ }^{R 206 H_{-} F l E x} ; M y d 88_{P d g f r a-/-}$ after tamoxifen-induced recombination), or Pdgfra ${ }^{c E 2 / w} ; A c v r 1^{R 206 H \_m g / R 206 H \_m g} ; M y d 88^{w / w}$ and Pdgfra ${ }^{c E 2 / w} ; A c v r 1^{R 206 H \_m g / R 206 H \_m g}$; Myd88f/f $\left(A c v r 1^{R 206 H \_m g} ; M y d 88^{w / w}\right.$ and Acvr1 ${ }^{R 206 H \_m g} ; M y d 88_{P d g f r a-/}$ after tamoxifen-induced recombination). Primers used for genotyping are listed in Table S1. Administration of tamoxifen (tam) to $R 26^{c E 2 / c E 2}$ mice results in "global" recombination of either of the Acvr1 $1^{R 206 H}$ conditional alleles and deletion of $M y d 88^{f l}$ alleles, while Pdgfra ${ }^{c E 2}$ limits tam-induced recombination to mesenchymal-like stem cells, which include only FAPs and pericytes in skeletal muscle $[10,20,39]$.

\subsection{Tamoxifen Treatment and Induction of Heterotopic Ossification in FOP Mice by Pinch Injury}

Mice were weaned at 21 days old and given ad libitum access to standard chow before being switched to tamoxifen-doped chow (TD.130856, Envigo, Indianapolis, IN, USA), formulated to deliver $\sim 40 \mathrm{mg} / \mathrm{kg} / \mathrm{d}$ for 8 days starting at 24-36 days of age. Tamoxifen chow was replaced with standard chow for 2 days before the mice were injured.

To induce EHO, all mice received bilateral pinch injuries of their lower hind limb muscles at 34-46 days of age. Mice were deeply anesthetized with $2-4 \%$ isoflurane in pure $\mathrm{O}_{2}$ and were monitored throughout the procedure. Each mouse received $0.5 \mathrm{mg} / \mathrm{kg}$ buprenorphine SR (ZooPharm, Rx 221356, Lot\# BSRLAB0.5-201103, Fort Collins, CO, USA) prior to muscle injury. The lower hindlimb muscles were injured as previously described by this and other labs [40]. In brief, the mice were laid prone or supine, depending on the leg to be injured, and the midsection of the gastrocnemius and adjacent muscles was localized using forceps by gently squeezing the muscle group from the posterior side of the tibia. Once localized, the forceps were squeezed until there was a 1-2 $\mathrm{mm}$ gap between its arms, and pressure was maintained for $5 \mathrm{~s}$. Care was taken to prevent movement or rotation of the forceps during the procedure, so as to prevent fracturing the fibula.

\subsection{Radiographs and Microcomputed Tomography (microCT)}

$\mathrm{HO}$ formation was monitored by in vivo plain radiographs acquired weekly after crush injury. Radiographs were acquired using an XPERT 40 digital radiography cabinet (Kubtec, Stratford CT, USA) at $40 \mathrm{kv}$ and $1000 \mu \mathrm{A}$. The HO area in each leg was semiquantified using ImageJ version 1.52p. All mice were humanely euthanized 21 days post-injury (dpi) by exsanguination and cervical dislocation under deep isoflurane anesthesia. Hind limbs were excised, the skin carefully removed, and fixed in 10\% neutral buffered formalin for $48 \mathrm{~h}$ before transfer to $70 \% \mathrm{EtOH}$.

Ex vivo microCT scans of each leg were acquired using a $\mu$ CT40 or $\mu$ CT50 (Scanco Medical AG, Wangen-Brüttisellen, Switzerland). All samples within each study were scanned on only one of the instruments. The $\mu \mathrm{CT} 40$ images were acquired at $70 \mathrm{kV}, 114 \mu \mathrm{A}$, and a $16 \mathrm{~mm}$ FOV, with 500 projections/rotation, an integration time of $300 \mathrm{~ms}$, and reconstructed with an isotropic voxel size of $16 \mu \mathrm{m}$. Images from the $\mu \mathrm{CT} 50$ were acquired at $55 \mathrm{kV}, 200 \mu \mathrm{A}$, and a $14 \mathrm{~mm}$ FOV, with 500 projections/rotation, $250 \mathrm{~ms}$ integration time, and reconstructed with $13.3 \mu \mathrm{m}$ isotropic voxels. IPL v5.42 (Scanco Medical AG, WangenBrüttisellen, Switzerland) was used to employ a semiautomated algorithm adapted from Buie et al. [41] to create a tight outer contour of the EHO lesions that defined the total lesion volume (including mineralized bone and the unmineralized interior of the $\mathrm{HO}$ ), and the mineralized $\mathrm{EHO}$ volume was determined using a standardized density threshold and noise filter. A cartoon of the workflow is provided in Figure S1. In brief, hand-drawn contours were used to create a boundary around the $\mathrm{HO}$ and precisely separate the $\mathrm{HO}$ 
from the host leg bones. The manual contour was used as an outer boundary in the subsequent automated creation of a contour that tightly outlined the perimeter of the mineralized ossicles while excluding the tibia and fibula. The total volume of the resulting mask is deemed "lesion volume" (LV) and includes both mineralized and unmineralized tissues in the ossicles. The mineralized portion of the $\mathrm{HO}$ within the lesion mask, referred to as mineralized volume (MV), was segmented using a threshold of $250 \mathrm{mg} \mathrm{HA} / \mathrm{ccm}$, sigma 0.3 , and support 2 .

\subsection{Histology}

After microCT scanning, the hind limbs were decalcified in 20\% EDTA on a shaker at room temperature for 14 days. Samples were dehydrated through graded ethanol, cleared in xylene or methyl salicylate, infiltrated, and embedded in paraffin. A standard rotary microtome (RM2255, Leica Biosystems, Wetzlar, Germany) was used to cut $5 \mu \mathrm{m}$ transverse sections that were stained with hematoxylin-eosin and examined under brightfield microscopy to evaluate muscle repair and the composition of $\mathrm{EHO}$.

\subsection{Isolation and Culture of Intramuscular Fibroadipoprogenitors}

\subsubsection{Skeletal Muscle Digestion}

To isolate skeletal muscle FAPs, 6 weeks old male mice were sacrificed under deep isoflurane anesthesia. Skeletal muscles were harvested from hind limbs and forelimbs. Tendons and ligaments were thoroughly removed from the muscle, and the cleaned muscle was weighed. Muscle tissue was divided into $0.5 \mathrm{~g}$ portions that were placed into individual $50 \mathrm{~mL}$ conical tubes containing $2.35 \mathrm{~mL}$ of "harvest media" (DMEM w/o phenol Rred [+] $4.5 \mathrm{~g} / \mathrm{L}$ glucose, [+] L-glutamine, sodium pyruvate, and $2 \%$ pen-strep) at $37{ }^{\circ} \mathrm{C}$. Samples were moved to a sterile biosafety cabinet, where they were finely diced using sterile scissors. An enzyme cocktail of $100 \mu \mathrm{L}$ Enzyme D, $50 \mu \mathrm{L}$ Enzyme R, and $12.5 \mu \mathrm{L}$ Enzyme A from the Miltenyi multitissue dissociation kit (Order no. 130110201, Miltenyi Biotec, Bergisch Gladbach, Germany) was added for every $0.5 \mathrm{~g}$ of muscle. The muscle was digested inside in shaking incubator at $200 \mathrm{rpm}$ set to $37^{\circ} \mathrm{C}$ for $1 \mathrm{~h}$ and then triturated using 25 and $10 \mathrm{~mL}$ serological pipets. The muscle was returned to the shaker for $30 \mathrm{~min}$ and triturated again until the suspension smoothly passed through the tip of a $10 \mathrm{~mL}$ serological pipet. The muscle cell suspension was filtered through 70 and $40 \mu \mathrm{m}$ cell strainers (cat. num. 22,363,548 and 22363547, Fisher Scientific, Waltham, MA, USA), and the flow-through was centrifuged at $400 \mathrm{rcf}$ for $20 \mathrm{~min}$ at $4{ }^{\circ} \mathrm{C}$.

\subsubsection{MACS and FACS}

Cell pellets were incubated on ice for $15 \mathrm{~min}$ with $80 \mu \mathrm{L}$ of ice-cold autoMACS rinsing solution (Order no. 130091222, lot:5180904365, Miltenyi Biotec, Bergisch Gladbach, Germany) and $20 \mu \mathrm{L}$ of depletion cocktail (Adipose progenitor isolation kit Order no. 130106639, lot:5190809170, Miltenyi Biotec), diluted to $2 \mathrm{~mL}$ with additional cold MACS buffer, and passed through a Miltenyi MACS LD column (Order no. 130042901, Lot:5190524007, Miltenyi Biotec). The flow-through containing CD45-/CD31-/TERT- cell fraction, containing FAPs, was collected into sterile conical tubes for further staining and FACS. The CD45+/C31+/TERT+ fraction of the cell suspensions was flushed from the columns and used as unstained FACS control cells after red cell lysis with ACK buffer for 1.5-2 $\mathrm{min}$ at room temperature.

Suspensions of CD45-/CD31-/TERT- cells from mice of the same genotype were pooled and centrifuged at $400 \mathrm{rcf}$ for $5 \mathrm{~min}$ at $4{ }^{\circ} \mathrm{C}$. Detailed antibody information is in Table S2. Cell pellets were resuspended in $200 \mu \mathrm{L}$ of MACs buffer containing $10 \mu \mathrm{L}$ of PE-labeled anti-PDGFRa Miltenyi REA antibody (Order no. 130-122-019, Miltenyi Biotec) and $6 \mu \mathrm{L}$ of APC-labeled anti-Sca1 Miltenyi REA antibody (Order no. 130-123-848, Miltenyi Biotec) per gram of initial muscle tissue and incubated in the dark for $30 \mathrm{~min}$. Cells were washed with $3 \mathrm{~mL}$ of FAP harvest media, pelleted, and finally resuspended in $300 \mu \mathrm{L}$ of FAP harvest media for flow sorting. PDGFRa and Sca-1 positive cells were 
sorted into $15 \mathrm{~mL}$ conical tubes containing $5 \mathrm{~mL}$ of FAP growth media (DMEM containing $4.5 \mathrm{~g} / \mathrm{L}$ glucose, L-glutamine and sodium pyruvate, 10\% FBS, 1\% P/S, and $10 \mathrm{ng} / \mathrm{mL}$ FGF2 (R\&D Systems, Minneapolis, MN, USA) by FACS Aria II (BD Biosciences, San Jose, CA, USA). The FACS gating strategy is shown in Figure S2.

\subsubsection{FAP Plating and Culture during Expansion}

FAPs from $R 26^{c E 2 / c E 2} ; A c v r 1^{w / w}$ or $R 26^{c E 2 / c E 2} ; A c v r 1^{R 206 H_{-} F l E x /+}$ mice were plated in 1 well of a 24-well standard tissue culture plate (Corning, Tewksbury, MA, USA) in FAP growth media, and the media was changed every 3 days until the cells reached $70-80 \%$ confluence. The cells were then trypsinized and replated at $6000-10,000$ cells $/ \mathrm{cm}^{2}$. After 3-4 passages, the cells were treated with $500 \mathrm{nM}$ 4-OH tamoxifen (SLBZ7608, SigmaAldrich, St. Louis, MO, USA) for $48 \mathrm{~h}$ to induce cre-mediated recombination (Figure S2). Following $24 \mathrm{~h}$ of recovery from 4-OHT treatment, the cells were passaged and replated at 6000 cells $/ \mathrm{cm}^{2}$ in 6-well plates and grown to $70-80 \%$ confluence for experimental use.

\subsection{FAP Treatments and Measurement of Smad1/5 Phosphorylation by Western Blot}

FAPs were serum starved in DMEM with 0.1\% FBS, without FGF2 for 14-18 h. Then, experimental treatments were added according to the durations indicated in the corresponding figures. Cells were lysed using RIPA lysis buffer (R0278, Sigma-Aldrich, St. Louis, MO, USA) containing $1 \%$ protease inhibitor cocktail (P8340, Sigma), 5\% protease inhibitor cocktail (P8465, Sigma-Aldrich), 1\% phosphatase inhibitor Cocktail 2 (P5726, Sigma-Aldrich), and 1\% phosphatase inhibitor cocktail 3 (P0044, Sigma-Aldrich). The samples were centrifuged at 10,000 $\mathrm{rcf}$ for $15 \mathrm{~min}$ at $4{ }^{\circ} \mathrm{C}$, and the supernatant was collected and stored at $-20{ }^{\circ} \mathrm{C}$. Protein concentration was measured by BCA Protein Assay Kit (23225, Thermo Fisher Scientific, Waltham, MA, USA). In total, $8.4 \mathrm{ng}$ of protein per sample was separated by PAGE in 10\% acrylamide gels (4561033, Bio-Rad Laboratories, Hercules, CA, USA) and transferred to PVDF membranes using Trans-Blot Turbo Transfer System (Bio-Rad). PVDF membranes were blocked with 5\% BSA in TBST (0.1\% Tween 20) for $1 \mathrm{~h}$ at room temperature. The membranes were then incubated with primary antibodies for $\mathrm{p}-\mathrm{Smad} 1 / 5$, Smad $1 / 5$, or $\beta$-actin overnight at $4{ }^{\circ} \mathrm{C}$, followed by incubation with appropriate HRPlinked secondary antibodies for $1 \mathrm{~h}$ at room temperature. Detailed antibody information is in Table S3. Labeled protein was detected by chemiluminescence (Western Lightning Plus-ECL, PerkinElmer, Waltham, MA, USA) using the ChemiDocMP imaging system (Bio-Rad), and bands were quantified using ImageLab version 6.1 (Bio-Rad).

\subsection{Statistical Analysis}

Data sets that passed tests of normality and equal variance were analyzed by Student's $t$-test, one-way, or two-way ANOVA with Tukey's post hoc test and are presented as mean \pm SEM. Data that did not display normal distribution or equal variance were analyzed by the corresponding nonparametric test and post hoc test and are presented with median and interquartile ranges. The specific method used for each data set is described in the respective figure legend. A $p$-value $<0.05$ was considered statistically significant.

\section{Results}

\subsection{Activation of MyD88-Dependent Signaling Pathways Enhances Aberrant ActA-Induced} Smad1/5 Phosphorylation in FOP FAPs

To determine whether TLR or IL1R1 signaling enhances ActA/Alk $2^{\mathrm{R} 206 \mathrm{H}}$ signaling, phosphorylation of Smad1/5 was measured in murine $A l k 2^{w / w}$ and $A l k 2^{R 206 H_{-} F l E x / w}$ FAPs treated with ActA alone or in combination with LPS or IL-1 $\beta$ (Figure 1). As expected, treatment of serum starved FAPs with LPS or IL- $1 \beta$ did not alter pSmad1/5, regardless of Alk2 ${ }^{\mathrm{R} 206 \mathrm{H}}$ expression. In $A l k 2^{w / w}$ FAPs, ActA decreased endogenous $\mathrm{pSmad} 1 / 5$, regardless of costimulation with LPS or IL-1 $\beta$. However, in $A l k 2^{R 206 H / w}$ FAPs, ActA increased pSmad1/5, which was further enhanced by cotreatment with LPS or IL- $1 \beta$ (Figure 1). This confirms that ligands which activate MyD88-dependent signaling pathways can enhance 
aberrant ActA/Alk2 ${ }^{\mathrm{R} 206 \mathrm{H}}$-induced pSmad1/5 in a manner similar to that reported for BMP-induced signaling in Alk2 ${ }^{w t}$ cells [27-30] and cells from FOP patients [31].

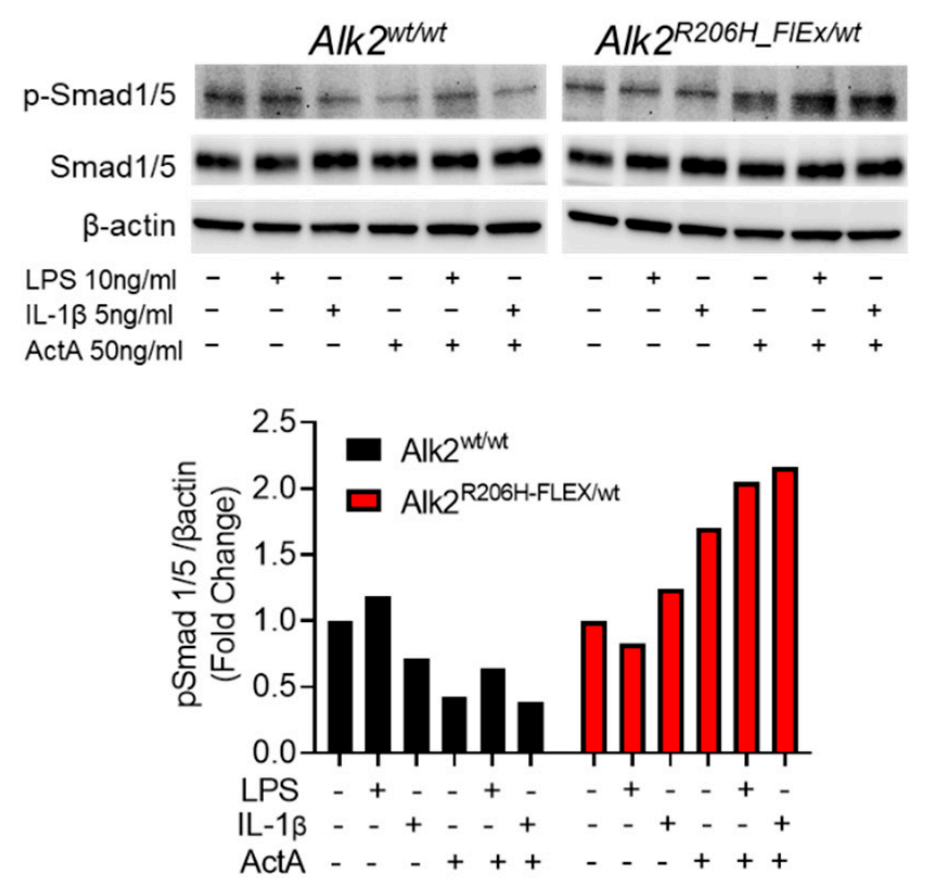

Figure 1. ActA-stimulated canonical BMP signaling in FAPs from FOP mice is enhanced by TLR or IL1R1 ligands. FAPs harvested from the hindlimb muscles of mice with the indicated genotypes were expanded in the presence of $10 \mathrm{ng} / \mathrm{mL}$ rhFGF2, serum starved overnight, then stimulated with the indicated ligands for $15 \mathrm{~min}$. In $A l k 2^{\text {wt } / w t}$ FAPs, pSmad1/5 was unaffected by LPS or ActA alone but decreased by IL-1 $\beta$ alone or in combination with ActA. However, in FAPs expressing Alk2 ${ }^{R 206 H}$, pSmad1/ 5 was increased by ActA alone, and this was further increased by addition of LPS or IL- $1 \beta$.

\subsection{Conditional Deletion of MyD88 in Pdfgra-Positive Cells Does Not Alter the Volume of Injury-Induced EHO}

Although previously published studies and the data in Figure 1 consistently demonstrate that activation of MyD88-dependent signaling enhances canonical signaling of type 1 $\mathrm{BMP}$ receptors in vitro, a role for these interactions in $\mathrm{EHO}$ has not been reported. Activation of MyD88-dependent signaling has complex, pleiotropic effects on numerous cellular processes including activation, differentiation, and apoptosis that are largely dependent on cell type [42-47]. Intramuscular FAPs are the primary source of chondrogenic progenitors in FOP mice $[9,10]$ and have previously been targeted in FOP mice using Pdgfracre $[10$, 20,48]. Thus, Pdgfra ${ }^{c E 2} ; A c v r 1^{R 206 H_{-} F I E x} ; M y d 88^{w / w}$ and Pdgfra ${ }^{c E 2} ; A c v r 1^{R 206 H_{-} F I E x} ; M y d 88^{f / f}$ mice (respectively, Acvr1 ${ }^{R 206 H_{-} F l E x} ; M y d 88^{w / w}$ and Acvr1 ${ }^{\text {R206H_FlEx }} ; M y d 88_{\text {Pdgfra-/-) }}$ ) were used to examine the role of MyD88-dependent signaling in FAPs during injury-induced HO formation.

Conditional recombination of both Acvr1 ${ }^{R 206 H_{-} F l E x}$ and Myd88-flox alleles in intramuscular FAPs was confirmed in two ways: (1) using conventional PCR of gDNA from ear punches collected from mice before and after tamoxifen treatment and (2) using FAPs isolated from the skeletal muscle of mice after tamoxifen treatment. As expected, little or no recombination was detected in ear punches, while a high rate of in vivo recombination of both floxed genes was found in FAPs isolated from tamoxifen treated

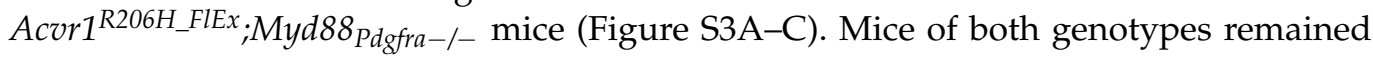
healthy and gained weight throughout 21 days post-injury (dpi); however, weight gain began to plateau during the third week due to HO-related restricted ambulation, which reduced access to food. The change in bodyweight was identical between genotypes except for a nonsignificant divergence at 21 dpi (Figure S3D). 
Analysis of in vivo radiographs showed that the area of mineralized HO in Acvr1 ${ }^{\text {R206H_FlEx }}$;

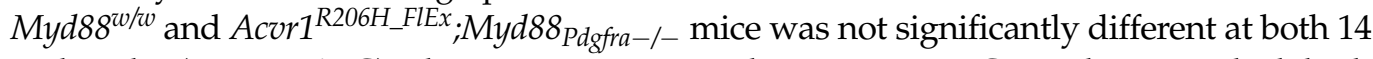
and $21 \mathrm{dpi}$ (Figure 2A-C). This was consistent with ex vivo microCT analysis, in which both total lesion volume and mineralized volume were not significantly altered by deletion of Myd88 in Pdgfra-positive cells (Figure 2D-G).

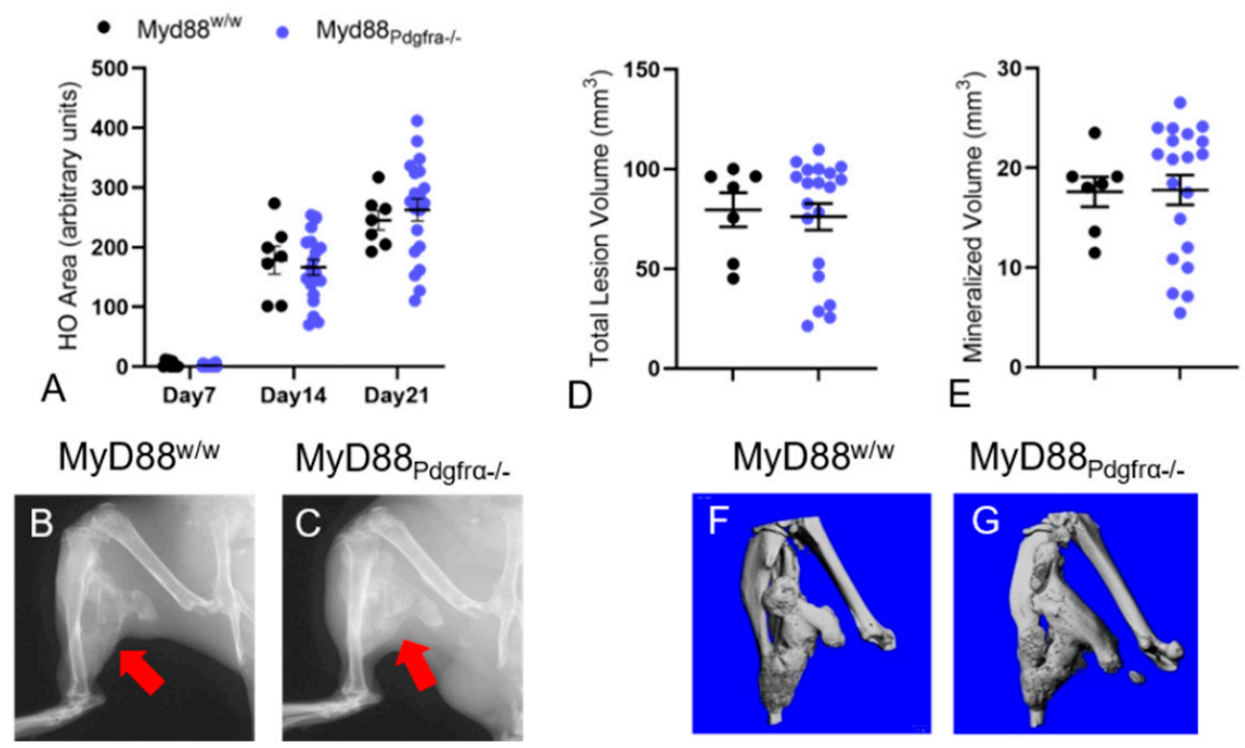

Figure 2. Conditional deletion of MyD88 in PDGFR $\alpha+$ cells in Acvr1 ${ }^{R 206 H \_F l E x / w t}$ mice did not affect muscle injury-induced EHO area and volume. (A) Semiquantification of intramuscular HO area in radiographs and $(\mathrm{D}, \mathrm{E}) \mu \mathrm{CT}$-based quantification of $\mathrm{HO}$ volume demonstrated unaffected $\mathrm{HO}$ area (A), total lesion volume (D), and mineralized volume (E) in Acvr1 ${ }^{\text {R206H_FlEx }} ; M y D 88_{P d g f r \alpha-/-}$ vs. Acvr1 ${ }^{R 206 H_{-} F l E x} ; M y D 88^{w / w}$ mice. Representative radiographs $(\mathbf{B}, \mathbf{C})$ and $\mu C T$ reconstructions $(\mathbf{F}, \mathrm{G})$ of representative samples at 21 dpi illustrating extensive EHO (red arrows) in both genotypes. Statistical significance was tested using Kruskal-Wallis test or a two-tailed unpaired Student's $t$-test. No significant differences were found.

Following the microCT scanning, the maturity and composition of the EHO lesions was examined histologically in H\&E-stained sections. In Acvr1 ${ }^{R 206 H \_F l E x} ; M y d 88^{w / w}$ mice, EHO lesions had transitioned from cartilage to ossicles of thin lamellar bone surrounding bone marrow, with few or no trabeculae (Figure 3A,B), as is typical in this model. Careful

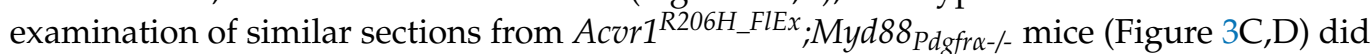
not reveal any gross differences in the maturity, structure, or composition of the EHO compared to the Acvr $1^{R 206 H_{-} F l E x} ; M y d 88^{w / w}$ mice. While a detailed analysis might still find minor differences in ossicle remodeling or marrow composition, these gross observations demonstrate that deletion of MyD88 in Pdgfr $\alpha$-positive cells did not impair maturation of the EHO in this model. 


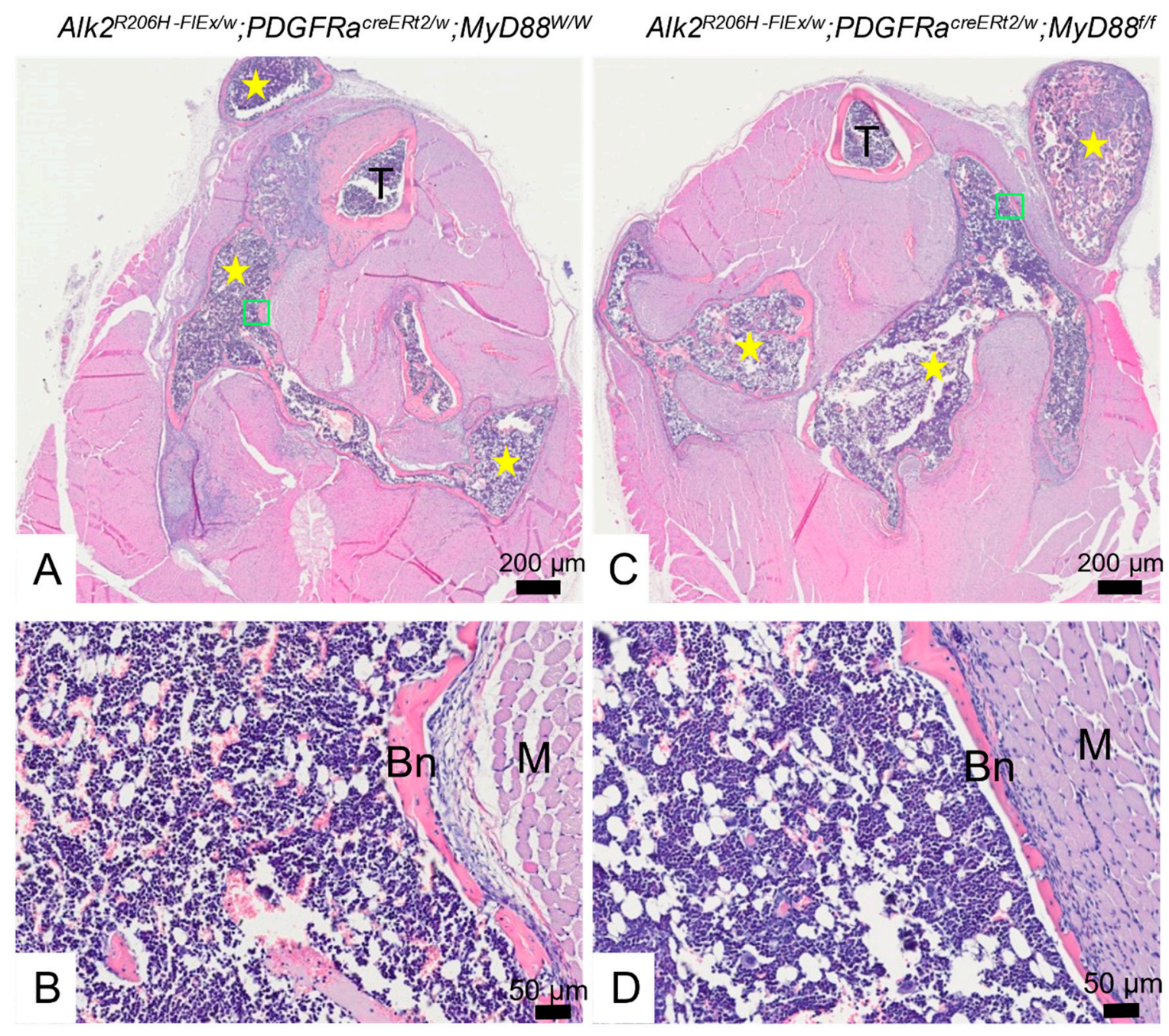

Figure 3. Gross histological examination of EHO in injured hindlimbs of Acvr1 ${ }^{R 206 H_{-} F l E x} ; M y D 88^{w / w}(\mathbf{A}, \mathbf{B})$ and Acvr1 ${ }^{\text {R206H_FlEx;MyD88 }}$ Pdgfra-/- (C,D) mice. The tissue and cellular composition of injured lower hindlimbs was examined in H\&E-stained transverse sections of decalcified paraffin embedded specimens collected 21 dpi. Legs from both genotypes consistently contained large amounts of mature intramuscular heterotopic bone (yellow stars in $(\mathbf{A}, \mathbf{C})$ ) filled with bone marrow with an unremarkable composition of hematopoietic cells, adipocytes, and erythrocytes (B,D) that appeared similar to that in host tibia $(\mathrm{T})$. The green boxes in $(\mathbf{A}, \mathbf{C})$ mark the approximate locations of the images in $(\mathbf{B}, \mathbf{D})$. Bn $=$ bone, $\mathrm{M}=$ muscle, and $\mathrm{T}=$ tibia.

To confirm these results, a similar study was conducted using Acvr1 $1^{R 206 H \_m g / R 206 H \_m g}$ mice in which cre-mediated recombination induced homozygous expression of Alk2 ${ }^{\mathrm{R} 206 \mathrm{H}}$. Recombination of the $A c v r 1^{R 206 H \_m g}$ and $M y D 88^{f l}$ alleles was confirmed by PCR, as in the previous study (Figure S4A,B). As in the Acvr1 $1^{R 206 H_{-} F l E x}$ mice, the area of EHO measured in radiographs at 14 and 21dpi did not significantly differ between groups (Figure S5A-C). Likewise, total lesion volume and mineralized volume of the EHO at 21 days post-injury were not significantly altered by deletion of MyD88 in cells of the Pdgfr $\alpha$-positive lineage (Figure S5D-G). Therefore, MyD88-dependent signaling in intramuscular FAPs and other mesenchymal cells does not appear to be critical for EHO in FOP mice.

\subsection{Global Deletion of MyD88 does Not Alter Muscle Injury-Induced EHO Formation in FOP Mice}

MyD88 is best known for its roles in mediating TLR, and IL1R1 inflammatory signals in innate immune cells, including monocytes and macrophages, have important but poorly characterized roles in multiple mouse models of genetically driven and traumatic 
EHO [24-26,49-51], including FOP mice [25]. Therefore, muscle injury-induced EHO was studied in Acvr1 ${ }^{\text {R206H_FlEx}} ; M y d 88^{w / w}$ and Acvr1 ${ }^{\text {R206H_FlEx }} ; M y d 88^{-/-}$mice in which expression of $A l k 2^{R 206 H}$ and deletion of $M y D 88^{f l}$ were globally induced using R26cre ${ }^{\mathrm{ER} 22}$. Recombination of both $A_{c v r}{ }^{R 206 H_{-} F I E x}$ and Myd88-flox alleles prior to injury was confirmed in all mice via conventional PCR of gDNA from ear punches (Figure S6A,B). Mice of both genotypes remained healthy and gained weight throughout the 21-day post-injury period, with similar changes in bodyweight between genotypes except for a transient divergence at 14 dpi (Figure S6C).

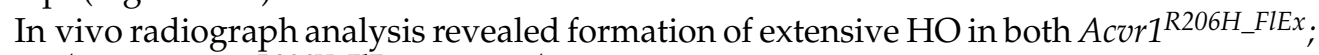
$M y d 88^{w / w}$ and Acvr1 ${ }^{R 206 H_{-} F l E x} ; M y d 88^{-/-}$FOP mice during the 21-day post-injury period, but, surprisingly, the area of radiographic $\mathrm{HO}$ was not different between genotypes (Figure $4 \mathrm{~A}-\mathrm{C}$ ). This was confirmed by ex vivo microCT analysis, which also did not demonstrate significant differences in lesion volume or mineralized volume (Figure 4D-E). Together, these data suggest that, even in myeloid and other cell types, MyD88 and MyD88dependent signaling do not have a significant role in the formation of EHO in FOP mice.
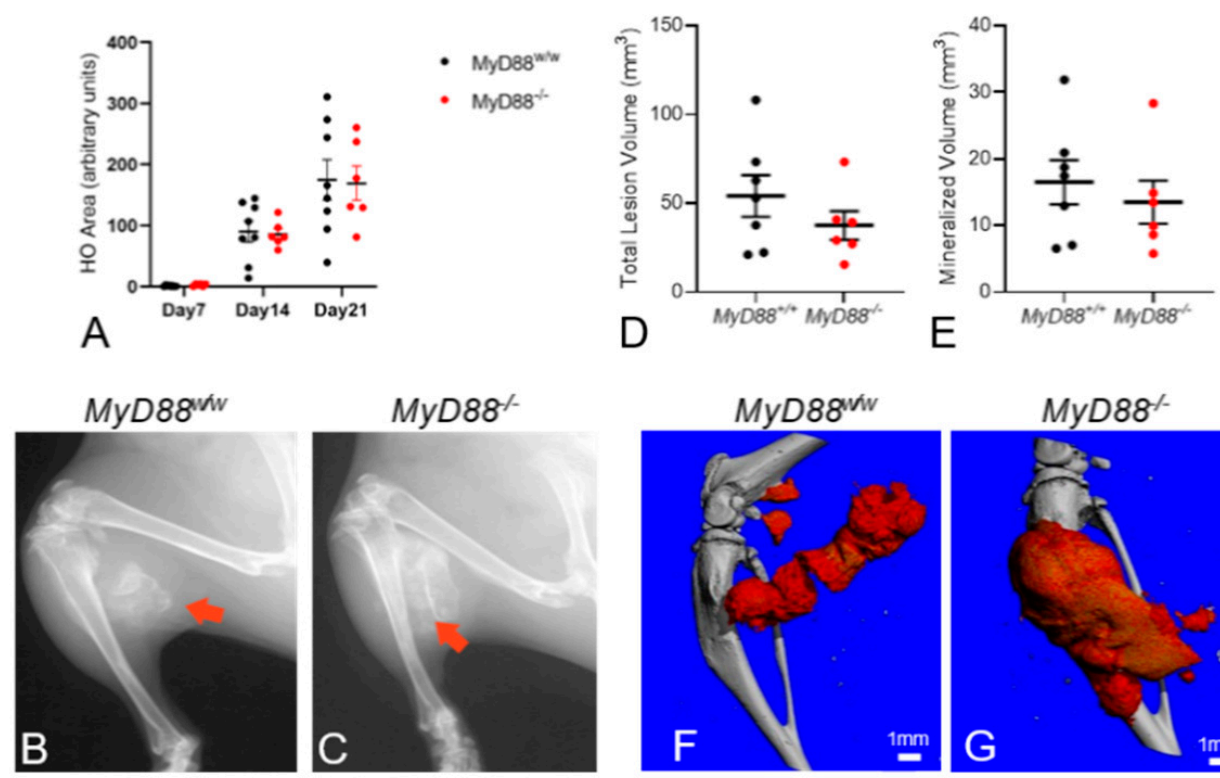

Figure 4. Global deletion of MyD88 in Acvr1 $1^{R 206 H \_F l E x / w t}$ FOP mice did not affect muscle injuryinduced EHO lesions. (A) Semiquantification of intramuscular $\mathrm{HO}$ area in in vivo radiographs at 7, 14, and 21 dpi. $\mu$ CT-based quantification of $\mathrm{HO}$ demonstrated that (D) total lesion volume and (E) mineralized volume were unaffected in $M y D 88^{-/-}$FOP mice compared to MyD $88^{w / w}$ FOP mice. Representative radiographs $(\mathbf{B}, \mathbf{C})$ and $\mu \mathrm{CT}$ reconstructions $(\mathbf{F}, \mathbf{G})$ of legs at $21 \mathrm{dpi}$ in $M y D 88^{w / w}$ and $M y D 88^{-/-}$FOP mice illustrated large intramuscular HO (red arrow and red material). Statistical significance was tested using Kruskal-Wallis test or a two-tailed unpaired Student's $t$-test. No significant differences were found.

While this study was not designed for detailed histomorphometric analysis of bone remodeling within $\mathrm{HO}, \mathrm{H} \& \mathrm{E}-$ stained sections of the decalcified hindlimbs were qualitatively assessed for obvious differences in $\mathrm{HO}$ morphology, maturation, marrow composition, and resorption of mineralized cartilage and bone. Lesions in Acvr1 ${ }^{R 206 H_{-} F l E x} ; M y d 88^{w / w}$ mice exhibited the typical EHO morphology and composition seen at 21 days (Figure 5A) as in the previous study above. Mature heterotopic ossicles contained a primarily hematopoietic bone marrow that included adipocytes and scattered areas of erythropoiesis with little or no trabeculated bone structures. In Acvr1 ${ }^{R 206 H_{-} F l E x} ; M y d 88^{-/-}$mice, $\mathrm{HO}$ was also clearly endochondral and most of the $\mathrm{HO}$ lesions were composed similar to those in $A c v r 1^{R 206 H_{-} F l E x} ; M y d 88^{w / w}$ mice. However, some of the ossicles in these mice lacked a well-defined cortex-like shell, and the bone appeared as disorganized and disconnected 
trabeculae surrounded by dysplastic bone marrow, excessive erythropoiesis, and acellular areas of extracellular matrix (ECM) (Figure 5B). The composition of marrow in EHO ossicles was consistent with the bone marrow phenotypes seen in the respective intact host bones (Figure 5E,F). This suggests the dysplastic marrow associated with EHO lesions of $\mathrm{MyD} 88^{-/-}$mice is not unique to the EHO process but rather a symptom of the known effects of MyD88 deletion on hematopoietic cells [52-56].

\section{Acvr1 R206H_FIEx/w;MyD88w/w}
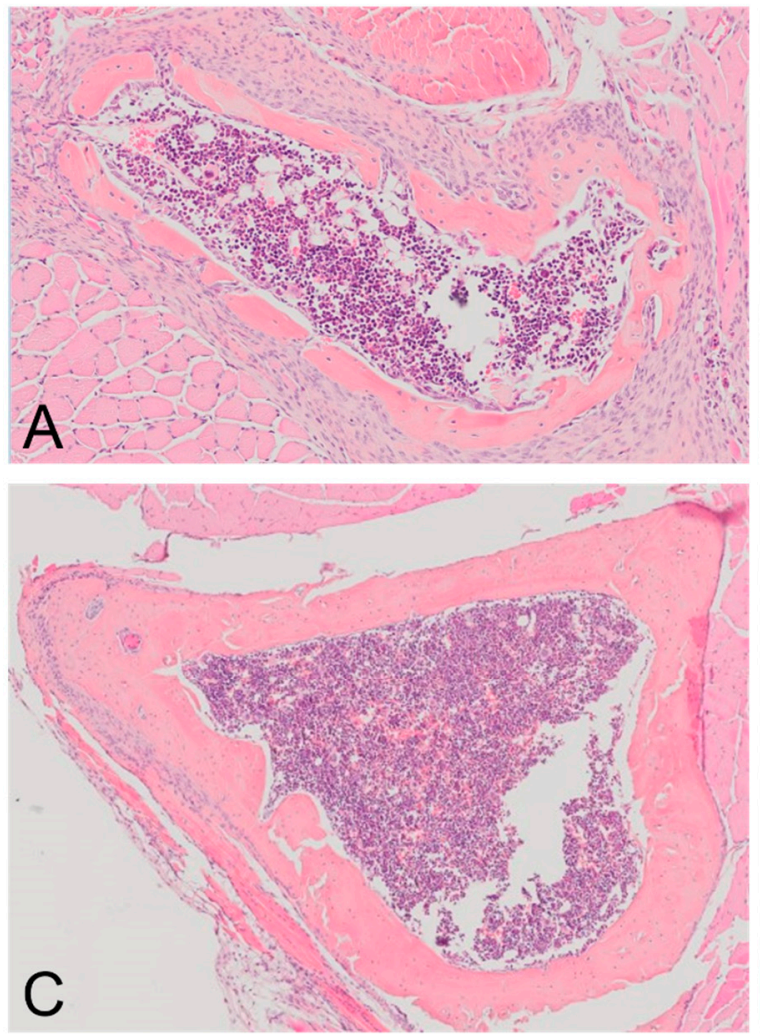

Acvr1R206H_FIEx/w;MyD88-/-
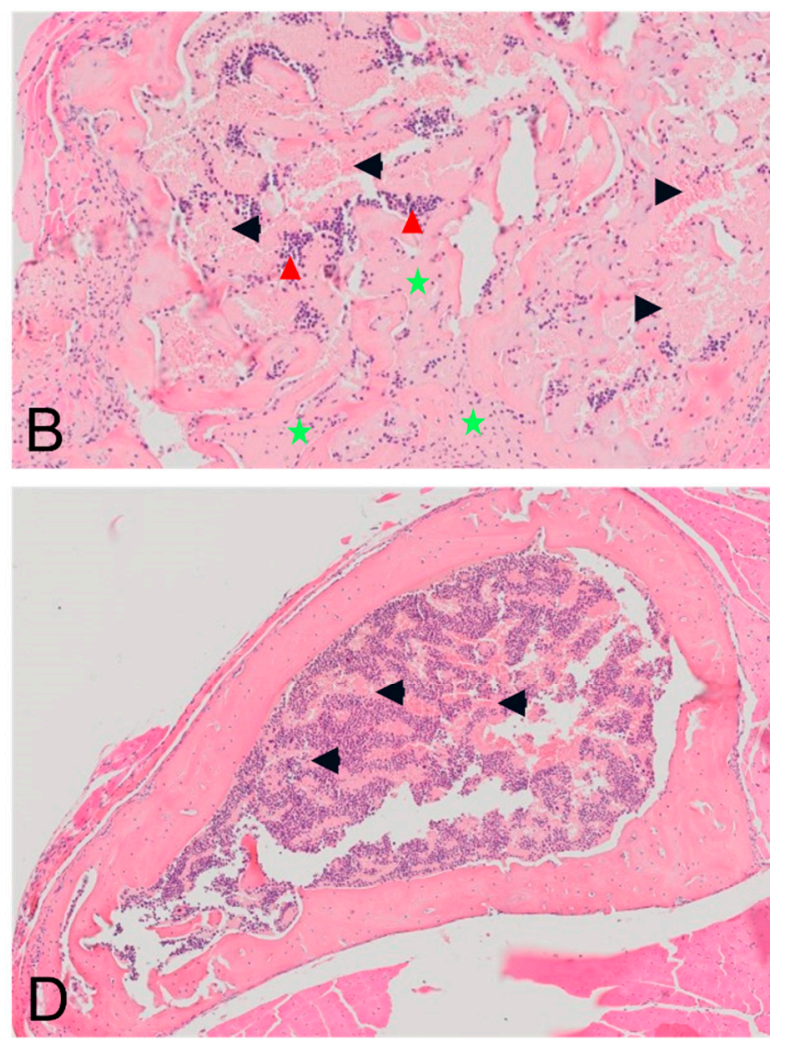

Figure 5. Representative H\&E-stained sections of intramuscular EHO lesions and host tibias in Acvr1 ${ }^{R 206 H \_F l E x} ; M y d 88^{\text {ww/w }}$ and $A c v r 1^{R 206 H_{-} F l E x} ; M y d 88^{-/-}$FOP mice 21 dpi. Images are representative micrographs of intramuscular EHO lesions $(\mathbf{A}, \mathbf{B})$ and host tibias (C,D) in the same sections of decalcified paraffin embedded sections stained with H\&E. (A) A typical mature ossicle of EHO in the hindlimb muscle of an Acvr1 ${ }^{R 206 H_{-} F l E x} ;$ Myd8 $88^{w / w}$ mouse. While most EHO ossicles in $A c v r 1^{R 206 H \_F l E x} ; M y d 88^{-/-}$mice were similar to that shown in panel A, some ossicles in Acvr1 ${ }^{R 206 H_{-} F l E x} ;{ }_{;} M y d 88^{-/-}$mice exhibited a disorganized structure (B). Note the striking differences in bone organization and soft tissue composition inside the ossicles, including the presence of dysplastic immature immune cells (red arrow heads), excessive erythropoiesis (black arrows), and areas of extracellular matrix accumulation (green stars). (C,D)—Lox magnification images of tibiae adjacent to the lesions in $(\mathbf{A}, \mathbf{B})$, illustrating bone marrow composition similar to that of the respective EHO.

Less mature areas of EHO in $M y D 88^{w / w}$ mice also included areas in which mineralized cartilage was rapidly being remodeled to lamellar bone and marrow-filled medullary spaces (Figure 5C). As expected, these areas contained a high density of multinucleated osteoclasts (OCL), the bone surface was predominantly scalloped and eroded, and groups of bone forming osteoblasts $(\mathrm{OB})$ were seen in close proximity. Resorbed space between the remaining bone was rapidly filling with a mixture of immune cells similar to typical healthy bone marrow. In contrast, similar areas of transition from cartilage to bone in $M y D 88^{-/-}$FOP mice were wider than in $M y D 88^{w / w}$ FOP mice and contained few small osteoclasts, and the resorption spaces were dominated by fibroblasts and osteogenic cells rather than hematopoietic cells (Figure 5D). Resorption areas that were large enough for marrow cell invasion were often filled with acellular matrix, resembling collagen 
deposition (Figure 5D). While these histological observations suggest the remodeling of cartilage to bone may be impaired in $M y D 88^{-/}$FOP mice, this study demonstrates that MyD88-dependent signaling has a surprisingly limited, if any, role during EHO in FOP.

\section{Discussion}

FOP flares and the ensuing formation, remodeling, and expansion of heterotopic ossification involve complex interactions between numerous cell types that are most notably of migratory hematopoietic lineages $[25,50,57-59]$ and mesenchymal lineages that derive from both local intramuscular and distant stem cell populations $[9,10,13,19,48]$. Since the cellular responses to TLR and IL1R1 ligands vary greatly according to cell type, the mechanisms by which their signaling pathways regulate EHO, if any, must be determined in a linage-specific manner.

$P d g f r \alpha+$ intramuscular FAPs appear to be the primary source of chondrogenic progenitors in FOP, and expression of Alk2 ${ }^{\mathrm{R} 206 \mathrm{H}}$ in FAPs is required for HO formation in FOP mice $[9,10]$. Previous reports demonstrated that TLR and IL1R1 signaling, activated by LPS and IL-1 $\beta$, respectively, enhanced BMP-induced phosphorylation and/or transcriptional activity of Smad1/5/8 in fibroblasts from FOP patients [31] and other cell types [28,29,36,37] but did not utilize intramuscular FAPs. Therefore, the observation that LPS or IL-1 $\beta$ enhanced aberrant ActA-induced pSmad1/5 in FAPs from FOP mice (Figure 1) is novel but not surprising. While FOP flares are a sterile process that does not appear to involve exposure to bacterial LPS, it is widely used as a broad activator of TLR signaling pathways via TLR2 and TLR4, which are also activated by multiple DAMPs [60,61]. The broad consistency among in vitro systems provided a strong rationale for the hypothesis that one or more pathways activated by TLRs and IL1R1 may contribute to chondrogenesis of FAPs in FOP mice.

Although not required for all TLR and IL1R1 signaling, the adapter protein MyD88 was an attractive target for initial in vivo studies interrogating the roles of these pathways in FOP. TLR and IL1R1 ligands released from damaged tissues may be composed of up to three dozen unique molecules [60-62], making ligand-targeted studies unreasonable. Even when focusing on LPS and IL-1 $\beta$, the ligands activate a variety of redundant receptors and intracellular signaling pathways, preventing any one approach from blocking all potential signals. However, MyD88 is a required adapter protein in most, but not all, LPS- and IL-1 $\beta$-activated signaling pathways, making it the most reasonable first target for in vivo studies aimed at determining a potential role for TLR and/or IL1R1 activation in FOP.

The current studies utilized inducible models of MyD88 deletion in an attempt to separate a potential direct role for MyD88 signaling from indirect effects via the hematopoietic phenotype of germline MyD88 knockout mice. MyD88 plays essential roles in the early stages of hematopoiesis as well as the terminal differentiation of both myeloid and lymphoid cells. Dysfunction of MyD88 has also been linked to multiple hematopoietic disorders. For example, significantly lower antibody responses after vaccination were detected in MyD88-knockout mice [52], whereas enhanced activation of TLR-MyD88-initiated signaling appears to contribute to the pathogenesis of myelodysplastic syndrome [63]. MyD88 is also involved in osteoclast function induced by IL-1 $\beta$ and LPS, and MyD88deficient mice are osteopenic with reduced bone resorption and formation. [64]. Reports that osteoclasts may contribute to EHO in FOP mice $[65,66]$, provide another possibility for indirect effects of long-term MyD88 deletion. The effects may also provide an explanation for the histological observations in the ossicles of Acvr1 ${ }^{F l E x+R 206 H} ; M y D 88^{-/-}$mice.

Thus, the data in Figure 2 and Figure S5 clearly demonstrating that deletion of MyD88 in Pdgfr $\alpha$-positive FAPs did not alter EHO were rather surprising. Moreover, the failure of global MyD88-deletion to alter injury-induced EHO in FOP mice (Figure 4) was entirely unexpected given the well-established roles of MyD88 in inflammatory cells known to be important in FOP $[25,50,57,58]$.

When interpreting negative results, it is important to carefully examine experimental controls and limitations of the studies. One such limitation is the inability to directly 
confirm deletion of the $M y D 88^{f l}$ alleles in the FAPs of Pdgfra ${ }^{c E 2}$ mice in which HO was measured. However, Figures S3 and S4 demonstrate a high rate of MyD88 deletion in intramuscular FAPs in vivo, but not in ear punches, from tamoxifen-treated MyD88 Pdgfra-/mice. Cre-mediated recombination of the conditional $A l k 2^{R 206 H}$ alleles in Pdgfr $\alpha$-positive cells is required for injury-induced EHO in these models. Therefore, robust EHO is also a reliable surrogate for effective cre-mediated recombination in the targeted FAP population. Hence, it is very unlikely that the results of those experiments can be explained by inefficient MyD88 deletion. Finally, global recombination of the Alk2 $2^{R 206 H \_F l E x}$ allele and deletion of $M y D 88^{f l}$ alleles in the $R 26^{c E 2 / c E 2}$ mice was confirmed using ear tissue collected at the time of muscle injury (Figure S6). Together, these controls demonstrate a high rate of MyD88 deletion in the targeted cells in each experiment and support the conclusion that MyD88 and MyD88-dependent signaling are dispensable for muscle injury-induced EHO in FOP mice.

The likely elimination of MyD88-dependent pathways as contributors to FOP flares does not contradict or reduce the potential importance of crosstalk between aberrant BMP signaling and DAMP-induced inflammatory signals. Given the wealth of research in tissue repair and inflammation, it is difficult to envision a logical scenario in which all TLR and IL1R1 signaling is unnecessary for the misdirected muscle repair processes in FOP. Hence, the current studies provide important evidence that substantially reduces the number of candidate signaling pathways. Assuming that LPS signaling is, in fact, transduced only by TLRs, only TRAM and TRIF are known to activate MyD88-independent signaling at this time [67]. Interestingly, TLR4 can activate ECSIT, which was previously reported to mediate TLR/BMPR crosstalk [27,31], via the MyD88-independent TRIF > RIP1 > Ubc13 pathway. IL-1 $\beta /$ IL1R1 can also activate a MyD88-independent pathway involving an IRAK2/TRAF6/ECSIT complex leading to activation of a MAPK cascade $[68,69]$. Thus, while the hypothesis for the current studies appears to have been disproven, they have narrowed the number of potential TLR and IL-1 $\beta$ signaling pathways that may mediate innate inflammatory crosstalk with BMP signaling and contribute to FOP flares and EHO.

Supplementary Materials: The following are available online at https:/ / www.mdpi.com/article/10 .3390 /biomedicines9060630/s1, Figure S1: Workflow of semiautomated microCT contouring process, Figure S2: Isolation of FAPs and in vitro recombination of Alk2 ${ }^{\text {R206H_FlEx }}$ allele, Figure S3: Postinjury changes in body weight and representative tamoxifen-induced recombination in $\mathrm{Pdgfra}^{\mathrm{cE} 2}$; Acvr1 ${ }^{\text {R206H_FlEx/w }}$;MyD88 mice, Figure S4: Post-injury changes in body weight and representative tamoxifen-induced recombination in Pdgfra ${ }^{\mathrm{CE} 2}$;Acvr1 ${ }^{\mathrm{R} 206 \mathrm{H}} \_\mathrm{mg} / \mathrm{R} 206 \mathrm{H} \_\mathrm{mg} ; \mathrm{MyD} 88$ mice, Figure S5: Conditional deletion of MyD88 in PDGFR $\alpha+$ cells did not alter injury-induced HO formation in

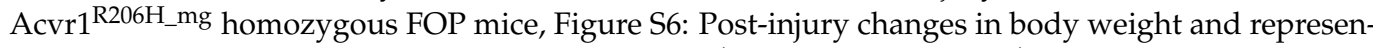
tative tamoxifen-induced recombination in R26 $6^{\mathrm{cE} 2 / \mathrm{cE} 2}$; Acvr1 ${ }^{\mathrm{R} 206 \mathrm{H}}{ }_{\text {FLEx/w}}$; Myd88 mice, Table S1: Primers used for genotyping by conventional PCR, Table S2: Fluorophore compensation cocktails used in FACS isolation of skeletal muscle FAPs, Table S3: Antibodies used for Western blots.

Author Contributions: The authors contributed to this publication as follows: conceptualization, D.S.P., C.H.S. and C.M.E.; methodology, C.M.E., D.S.P. and H.L.; validation, D.S.P., C.M.E. and H.L.; formal analysis, H.L., J.L.P. and D.S.P.; investigation, H.L., C.M.E., J.L.P. and D.S.P.; writing—original draft preparation, D.S.P. and H.L.; writing-review and editing, J.L.P., C.M.E., C.H.S. and D.S.P.; supervision, D.S.P.; project administration, D.S.P.; and funding acquisition, D.S.P. All authors have read and agreed to the published version of the manuscript.

Funding: This research was supported by funding from the National Institutes of Health/NIAMS, grants number R01AR073874 (DSP), R21AR067901 (DSP), NIH/NIBIB 1S10OD016204 (DSP) and NIH/NCRR 1S10RR027631 (DSP). JLP was supported by a NIH/NIAMS Diversity Supplement to R01AR073874 (DSP). Additional support was provided by the Vanderbilt Center for Bone Biology, Division of Clinical Pharmacology, and Department of Medicine at Vanderbilt University Medical Center, and the Division of Endocrinology, Metabolism, and Lipids in the Department of Medicine at Emory University. The creation of the Acvr $1^{R 026 H \_m g}$ mice was funded by a generous gift from La Jolla Pharmaceutical Company (La Jolla, CA, USA) to the International FOP Association (www.ifopa.org accessed on 25 May 2021), which owns the mice. 
Institutional Review Board Statement: The study was conducted according to ARRIVE guidelines and approved by the Institutional Animal Care and Use Committees of Vanderbilt University Medical Center under protocol M1800121, Approved 8 October, 2018 and Emory University under protocol 201900179, approved 4 November 2019.

Data Availability Statement: The data presented in this study are available in the article and Supplementary Material.

Acknowledgments: HL is a member of the joint training program between Emory University School of Medicine and Xiangya School of Medicine, Central South University, and is supported by the China Scholarship Council. The authors thank Regeneron Pharmaceuticals for generously providing the Acvr1 ${ }^{\text {R206H_FlEx }}$ mice, as well as Aris Economides and Sarah Hatsel at Regeneron for their protocols, support, and advice for using the Acvr1 ${ }^{F l E x \_R 206 H}$ mice. We thank the International FOP Association (www.ifopa.org accessed 25 May 2021) for providing the Acvr1 $1^{R 206 H \_m g}$ mice.

Conflicts of Interest: The authors declare no conflict of interest. The funders had no role in the design of the study; in the collection, analyses, or interpretation of data; in the writing of the manuscript, or in the decision to publish the results.

\section{References}

1. Shore, E.M.; Xu, M.; Feldman, G.J.; Fenstermacher, D.A.; Cho, T.J.; Choi, I.H.; Kaplan, F.S. A recurrent mutation in the BMP type I receptor Acvr1 causes inherited and sporadic fibrodysplasia ossificans progressiva. Nat. Genet. 2006, 38, 525-527. [CrossRef]

2. Huning, I.; Gillessen-Kaesbach, G. Fibrodysplasia Ossificans Progressiva: Clinical Course, Genetic Mutations and GenotypePhenotype Correlation. Mol. Syndromol. 2014, 5, 201-211. [CrossRef]

3. Smith, R.; Athanasou, N.A.; Vipond, S.E. Fibrodysplasia (myositis) ossificans progressiva: Clinicopathological features and natural history. QJM 1996, 89, 445-446. [CrossRef] [PubMed]

4. Virdi, A.S.; Shore, E.M.; Oreffo, R.O.; Li, M.; Connor, J.M.; Smith, R.; Kaplan, F.S.; Triffitt, J.T. Phenotypic and molecular heterogeneity in fibrodysplasia ossificans progressiva. Calcif. Tissue Int. 1999, 65, 250-255. [CrossRef] [PubMed]

5. Pignolo, R.J.; Shore, E.M.; Kaplan, F.S. Fibrodysplasia ossificans progressiva: Clinical and genetic aspects. Orphanet J. Rare Dis. 2011, 6, 80. [CrossRef] [PubMed]

6. Pignolo, R.J.; Bedford-Gay, C.; Liljesthrom, M.; Durbin-Johnson, B.P.; Shore, E.M.; Rocke, D.M.; Kaplan, F.S. The Natural History of Flare-Ups in Fibrodysplasia Ossificans Progressiva (FOP): A Comprehensive Global Assessment. J. Bone Miner. Res. 2016, 31, 650-656. [CrossRef]

7. Kaplan, F.S.; Al Mukaddam, M.; Pignolo, R.J. Longitudinal Patient-Reported Mobility Assessment In Fibrodysplasia Ossificans Progressiva (Fop). Bone 2017. [CrossRef] [PubMed]

8. Pignolo, R.J.; Durbin-Johnson, B.P.; Rocke, D.M.; Kaplan, F.S. Joint-Specific Risk Of Impaired Function In Fibrodysplasia Ossificans Progressiva (Fop). Bone 2017. [CrossRef]

9. Dey, D.; Bagarova, J.; Hatsell, S.J.; Armstrong, K.A.; Huang, L.; Ermann, J.; Vonner, A.J.; Shen, Y.; Mohedas, A.H.; Lee, A.; et al. Two tissue-resident progenitor lineages drive distinct phenotypes of heterotopic ossification. Sci. Transl. Med. 2016, 8, $366 \mathrm{ra163.}$ [CrossRef]

10. Lees-Shepard, J.B.; Yamamoto, M.; Biswas, A.A.; Stoessel, S.J.; Nicholas, S.E.; Cogswell, C.A.; Devarakonda, P.M.; Schneider, M.J., Jr.; Cummins, S.M.; Legendre, N.P.; et al. Activin-dependent signaling in fibro/adipogenic progenitors causes fibrodysplasia ossificans progressiva. Nat. Commun. 2018, 9, 471. [CrossRef]

11. Pulik, L.; Mierzejewski, B.; Ciemerych, M.A.; Brzoska, E.; Legosz, P. The Survey of Cells Responsible for Heterotopic Ossification Development in Skeletal Muscles-Human and Mouse Models. Cells 2020, 9, 1324. [CrossRef]

12. Feng, H.; Xing, W.; Han, Y.; Sun, J.; Kong, M.; Gao, B.; Yang, Y.; Yin, Z.; Chen, X.; Zhao, Y.; et al. Tendon-derived cathepsin K-expressing progenitor cells activate Hedgehog signaling to drive heterotopic ossification. J. Clin. Investig. 2020, 130, 6354-6365. [CrossRef] [PubMed]

13. Kan, C.; Ding, N.; Yang, J.; Tan, Z.; McGuire, T.L.; Lu, H.; Zhang, K.; Berger, D.M.P.; Kessler, J.A.; Kan, L. BMP-dependent, injury-induced stem cell niche as a mechanism of heterotopic ossification. Stem Cell Res. Ther. 2019, 10, 14. [CrossRef] [PubMed]

14. Kan, C.; Chen, L.; Hu, Y.; Ding, N.; Li, Y.; McGuire, T.L.; Lu, H.; Kessler, J.A.; Kan, L. Gli1-labeled adult mesenchymal stem/progenitor cells and hedgehog signaling contribute to endochondral heterotopic ossification. Bone 2018, 109, 71-79. [CrossRef] [PubMed]

15. Olmsted-Davis, E.A.; Salisbury, E.A.; Hoang, D.; Davis, E.L.; Lazard, Z.; Sonnet, C.; Davis, T.A.; Forsberg, J.A.; Davis, A.R. Progenitors in Peripheral Nerves Launch Heterotopic Ossification. Stem Cells Transl. Med. 2017, 6, 1109-1119. [CrossRef] [PubMed]

16. Agarwal, S.; Loder, S.J.; Sorkin, M.; Li, S.; Shrestha, S.; Zhao, B.; Mishina, Y.; James, A.W.; Levi, B. Analysis of Bone-CartilageStromal Progenitor Populations in Trauma Induced and Genetic Models of Heterotopic Ossification. Stem Cells 2016, 34, $1692-1701$. [CrossRef] 
17. Medina, A.; Ma, Z.; Varkey, M.; Liu, H.; Iwashina, T.; Ding, J.; Tredget, E.E. Fibrocytes participate in the development of heterotopic ossification. J. Burn Care Res. 2015, 36, 394-404. [CrossRef] [PubMed]

18. Downey, J.; Lauzier, D.; Kloen, P.; Klarskov, K.; Richter, M.; Hamdy, R.; Faucheux, N.; Scime, A.; Balg, F.; Grenier, G. Prospective heterotopic ossification progenitors in adult human skeletal muscle. Bone 2015, 71, 164-170. [CrossRef]

19. Kan, L.; Liu, Y.; McGuire, T.L.; Berger, D.M.; Awatramani, R.B.; Dymecki, S.M.; Kessler, J.A. Dysregulation of local stem/progenitor cells as a common cellular mechanism for heterotopic ossification. Stem Cells 2009, 27, 150-156. [CrossRef]

20. Wosczyna, M.N.; Biswas, A.A.; Cogswell, C.A.; Goldhamer, D.J. Multipotent Progenitors Resident In The Skeletal Muscle Interstitium Exhibit Robust Bmp-Dependent Osteogenic Activity And Mediate Heterotopic Ossification. J. Bone Miner. Res. 2012, 27, 1004-1017. [CrossRef]

21. Alessi Wolken, D.M.; Idone, V.; Hatsell, S.J.; Yu, P.B.; Economides, A.N. The Obligatory Role of Activin a in the Formation of Heterotopic Bone in Fibrodysplasia Ossificans Progressiva. Bone 2017. [CrossRef]

22. Hatsell, S.J.; Idone, V.; Wolken, D.M.; Huang, L.; Kim, H.J.; Wang, L.; Wen, X.; Nannuru, K.C.; Jimenez, J.; Xie, L.; et al. ACVR1R206H receptor mutation causes fibrodysplasia ossificans progressiva by imparting responsiveness to activin A. Sci. Transl. Med. 2015, 7, 303ra137. [CrossRef]

23. Upadhyay, J.; Xie, L.; Huang, L.; Das, N.; Stewart, R.C.; Lyon, M.C.; Palmer, K.; Rajamani, S.; Graul, C.; Lobo, M.; et al. The Expansion of Heterotopic Bone in Fibrodysplasia Ossificans Progressiva is Activin A-Dependent. J. Bone Miner. Res. 2017, 32, 2489-2499. [CrossRef] [PubMed]

24. Genet, F.; Kulina, I.; Vaquette, C.; Torossian, F.; Millard, S.; Pettit, A.R.; Sims, N.A.; Anginot, A.; Guerton, B.; Winkler, I.G.; et al. Neurological heterotopic ossification following spinal cord injury is triggered by macrophage-mediated inflammation in muscle. J. Pathol. 2015, 236, 229-240. [CrossRef] [PubMed]

25. Convente, M.R.; Chakkalakal, S.A.; Yang, E.; Caron, R.J.; Zhang, D.; Kambayashi, T.; Kaplan, F.S.; Shore, E.M. Depletion of Mast Cells and Macrophages Impairs Heterotopic Ossification in an Acvr1(R206H) Mouse Model of Fibrodysplasia Ossificans Progressiva. J. Bone Miner. Res. 2018, 33, 269-282. [CrossRef] [PubMed]

26. Levesque, J.P.; Sims, N.A.; Pettit, A.R.; Alexander, K.A.; Tseng, H.W.; Torossian, F.; Genet, F.; Lataillade, J.J.; Le Bousse-Kerdiles, M.C. Macrophages Driving Heterotopic Ossification: Convergence of Genetically-Driven and Trauma-Driven Mechanisms. J. Bone Miner. Res. 2018, 33, 365-366. [CrossRef] [PubMed]

27. Moustakas, A.; Heldin, C.H. Ecsit-ement on the crossroads of Toll and BMP signal transduction. Genes Dev. 2003, 17, 2855-2859. [CrossRef] [PubMed]

28. Su, X.; Ao, L.; Shi, Y.; Johnson, T.R.; Fullerton, D.A.; Meng, X. Oxidized low density lipoprotein induces bone morphogenetic protein-2 in coronary artery endothelial cells via Toll-like receptors 2 and 4. J. Biol. Chem. 2011, 286, 12213-12220. [CrossRef]

29. Yang, X.; Fullerton, D.A.; Su, X.; Ao, L.; Cleveland, J.C., Jr.; Meng, X. Pro-osteogenic phenotype of human aortic valve interstitial cells is associated with higher levels of Toll-like receptors 2 and 4 and enhanced expression of bone morphogenetic protein 2. J. Am. Coll. Cardiol. 2009, 53, 491-500. [CrossRef]

30. Huang, R.L.; Yuan, Y.; Zou, G.M.; Liu, G.; Tu, J.; Li, Q. LPS-stimulated inflammatory environment inhibits BMP-2-induced osteoblastic differentiation through crosstalk between TLR4/MyD88/NF-kB and BMP/Smad signaling. Stem. Cells Dev. 2014, 23, 277-289. [CrossRef]

31. Wang, H.; Behrens, E.M.; Pignolo, R.J.; Kaplan, F.S. ECSIT links TLR and BMP signaling in FOP connective tissue progenitor cells. Bone 2018, 109, 201-209. [CrossRef] [PubMed]

32. Ebert, S.; Zeretzke, M.; Nau, R.; Michel, U. Microglial cells and peritoneal macrophages release activin A upon stimulation with Toll-like receptor agonists. Neurosci. Lett. 2007, 413, 241-244. [CrossRef]

33. Liu, J.; Zhuang, Z.J.; Bian, D.X.; Ma, X.J.; Xun, Y.H.; Yang, W.J.; Luo, Y.; Liu, Y.L.; Jia, L.; Wang, Y.; et al. Toll-like receptor-4 signalling in the progression of non-alcoholic fatty liver disease induced by high-fat and high-fructose diet in mice. Clin. Exp. Pharmacol. Physiol. 2014, 41, 482-488. [CrossRef] [PubMed]

34. Winnall, W.R.; Muir, J.A.; Hedger, M.P. Differential responses of epithelial Sertoli cells of the rat testis to Toll-like receptor 2 and 4 ligands: Implications for studies of testicular inflammation using bacterial lipopolysaccharides. Innate Immun. 2011, 17, 123-136. [CrossRef] [PubMed]

35. Yamin, M.; Holbrook, E.H.; Gray, S.T.; Busaba, N.Y.; Lovett, B.; Hamilos, D.L. Profibrotic transforming growth factor beta 1 and activin A are increased in nasal polyp tissue and induced in nasal polyp epithelium by cigarette smoke and Toll-like receptor 3 ligation. Int. Forum. Allergy Rhinol. 2015, 5, 573-582. [CrossRef]

36. Zeng, Q.; Song, R.; Ao, L.; Xu, D.; Venardos, N.; Fullerton, D.A.; Meng, X. Augmented Osteogenic Responses In Human Aortic Valve Cells Exposed to Oxldl And Tlr4 Agonist: A Mechanistic Role of Notch1 And Nf-Kappab Interaction. PLoS ONE 2014, 9, e95400. [CrossRef]

37. Zhan, Q.; Song, R.; Zeng, Q.; Yao, Q.; Ao, L.; Xu, D.; Meng, X. Activation Of Tlr3 Induces Osteogenic Responses In Human Aortic Valve Interstitial Cells Through The Nf-Kappab And Erk1/2 Pathways. Int. J. Biol. Sci. 2015, 11, 482-493. [CrossRef]

38. Elkins, C.E.; Lyu, H.; Dave, S.; Roberts, R.; Hohl, M.; Perrien, D.S. Characterization of an inducible mouse model of fibrodysplasia ossificans progressiva utilizing both cre-lox and dre-rox recombinase systems. PLoS Biol. 2021. submitted.

39. Uezumi, A.; Ito, T.; Morikawa, D.; Shimizu, N.; Yoneda, T.; Segawa, M.; Yamaguchi, M.; Ogawa, R.; Matev, M.M.; Miyagoe-Suzuki, Y.; et al. Fibrosis and adipogenesis originate from a common mesenchymal progenitor in skeletal muscle. J. Cell Sci. 2011, 124 Pt 21,3654-3664. [CrossRef] 
40. Pan, H.; Fleming, N.; Hong, C.C.; Mishina, Y.; Perrien, D.S. Methods for the reliable induction of heterotopic ossification in the conditional Alk2(Q207D) mouse. J. Musculoskelet. Neuronal Interact. 2020, 20, 149-159.

41. Buie, H.R.; Campbell, G.M.; Klinck, R.J.; MacNeil, J.A.; Boyd, S.K. Automatic segmentation of cortical and trabecular compartments based on a dual threshold technique for in vivo micro-CT bone analysis. Bone 2007, 41, 505-515. [CrossRef] [PubMed]

42. Yu, S.; Cho, H.H.; Joo, H.J.; Bae, Y.C.; Jung, J.S. Role of MyD88 in TLR agonist-induced functional alterations of human adipose tissue-derived mesenchymal stem cells. Mol. Cell. Biochem. 2008, 317, 143-150. [CrossRef] [PubMed]

43. Hanke, M.L.; Angle, A.; Kielian, T. MyD88-dependent signaling influences fibrosis and alternative macrophage activation during Staphylococcus aureus biofilm infection. PLOS ONE 2012, 7, e42476. [CrossRef]

44. Nasi, S.; Ea, H.K.; Chobaz, V.; van Lent, P.; Lioté, F.; So, A.; Busso, N. Dispensable role of myeloid differentiation primary response gene 88 (MyD88) and MyD88-dependent toll-like receptors (TLRs) in a murine model of osteoarthritis. Jt. Bone Spine 2014, 81, 320-324. [CrossRef]

45. Leite, F.R.; de Aquino, S.G.; Guimarães, M.R.; Cirelli, J.A.; Zamboni, D.S.; Silva, J.S.; Junior, C.R. Relevance of the myeloid differentiation factor 88 (MyD88) on RANKL, OPG, and nod expressions induced by TLR and IL-1R signaling in bone marrow stromal cells. Inflammation 2015, 38, 1-8. [CrossRef] [PubMed]

46. Chu, X.; Xu, B.; Gao, H.; Li, B.Y.; Liu, Y.; Reiter, J.L.; Wang, Y. Lipopolysaccharides Improve Mesenchymal Stem Cell-Mediated Cardioprotection by MyD88 and stat3 Signaling in a Mouse Model of Cardiac Ischemia/Reperfusion Injury. Stem. Cells Dev. 2019, 28, 620-631. [CrossRef]

47. Gong, J.; Li, J.; Dong, H.; Chen, G.; Qin, X.; Hu, M.; Yuan, F.; Fang, K.; Wang, D.; Jiang, S.; et al. Inhibitory effects of berberine on proinflammatory M1 macrophage polarization through interfering with the interaction between TLR4 and MyD88. BMC Complement. Altern. Med. 2019, 19, 314. [CrossRef] [PubMed]

48. Lounev, V.Y.; Ramachandran, R.; Wosczyna, M.N.; Yamamoto, M.; Maidment, A.D.; Shore, E.M.; Kaplan, F.S. Identification of Progenitor Cells That Contribute To Heterotopic Skeletogenesis. J. Bone Jt. Surg. Am. 2009, 91, 652-663. [CrossRef]

49. Moraes, J.R.; Moraes, F.R. Effect of a persistent inflammatory process on experimental heterotopic ossification. The influence of macrophages. Braz. J. Med. Biol. Res. 1993, 26, 53-66.

50. Barruet, E.; Morales, B.M.; Cain, C.J.; Ton, A.N.; Wentworth, K.L.; Chan, T.V.; Moody, T.A.; Haks, M.C.; Ottenhoff, T.H.; Hellman, J.; et al. NF-kappaB/MAPK activation underlies ACVR1-mediated inflammation in human heterotopic ossification. JCI Insight 2018, 3. [CrossRef]

51. Sorkin, M.; Huber, A.K.; Hwang, C.; Carson, W.F.t.; Menon, R.; Li, J.; Vasquez, K.; Pagani, C.; Patel, N.; Li, S.; et al. Regulation of heterotopic ossification by monocytes in a mouse model of aberrant wound healing. Nat. Commun. 2020, 11, 722. [CrossRef] [PubMed]

52. Kang, S.M.; Yoo, D.G.; Kim, M.C.; Song, J.M.; Park, M.K.; Quan, F.S.; Akira, S.; Compans, R.W. MyD88 plays an essential role in inducing B cells capable of differentiating into antibody-secreting cells after vaccination. J. Virol. 2011, 85, 11391-11400. [CrossRef]

53. Li, C.; Huang, X.; Liu, Y.; Yang, T.; Zhang, L.; Li, M.; Jiang, F.; Huang, W.; Zhou, P. Dendritic cells play an essential role in transplantation responses via myeloid differentiation factor 88 signaling. Transpl. Proc. 2013, 45, 1842-1845. [CrossRef] [PubMed]

54. Ruud, J.; Wilhelms, D.B.; Nilsson, A.; Eskilsson, A.; Tang, Y.J.; Ströhle, P.; Caesar, R.; Schwaninger, M.; Wunderlich, T.; Bäckhed, F.; et al. Inflammation- and tumor-induced anorexia and weight loss require MyD88 in hematopoietic/myeloid cells but not in brain endothelial or neural cells. FASEB J. 2013, 27, 1973-1980. [CrossRef] [PubMed]

55. Fiedler, K.; Kokai, E.; Bresch, S.; Brunner, C. MyD88 is involved in myeloid as well as lymphoid hematopoiesis independent of the presence of a pathogen. Am. J. Blood Res. 2013, 3, 124-140.

56. Fuchs, A.; Monlish, D.A.; Ghosh, S.; Chang, S.W.; Bochicchio, G.V.; Schuettpelz, L.G.; Turnbull, I.R. Trauma Induces Emergency Hematopoiesis through IL-1/MyD88-Dependent Production of G-CSF. J. Immunol. 2019, 202, 3020-3032. [CrossRef]

57. Brennan, T.A.; Lindborg, C.M.; Bergbauer, C.R.; Wang, H.; Kaplan, F.S.; Pignolo, R.J. Mast cell inhibition as a therapeutic approach in fibrodysplasia ossificans progressiva (FOP). Bone 2017. [CrossRef]

58. Gannon, F.H.; Glaser, D.; Caron, R.; Thompson, L.D.; Shore, E.M.; Kaplan, F.S. Mast cell involvement in fibrodysplasia ossificans progressiva. Hum. Pathol. 2001, 32, 842-848. [CrossRef]

59. Kan, L.; Lounev, V.Y.; Pignolo, R.J.; Duan, L.; Liu, Y.; Stock, S.R.; McGuire, T.L.; Lu, B.; Gerard, N.P.; Shore, E.M.; et al. Substance P signaling mediates BMP-dependent heterotopic ossification. J. Cell. Biochem. 2011, 112, 2759-2772. [CrossRef]

60. Federico, S.; Pozzetti, L.; Papa, A.; Carullo, G.; Gemma, S.; Butini, S.; Campiani, G.; Relitti, N. Modulation of the Innate Immune Response by Targeting Toll-like Receptors: A Perspective on Their Agonists and Antagonists. J. Med. Chem. 2020, 63, 13466-13513. [CrossRef]

61. Jiang, L.; Shao, Y.; Tian, Y.; Ouyang, C.; Wang, X. Nuclear Alarmin Cytokines in Inflammation. J. Immunol. Res. 2020, 2020, 7206451. [CrossRef] [PubMed]

62. Murao, A.; Aziz, M.; Wang, H.; Brenner, M.; Wang, P. Release mechanisms of major DAMPs. Apoptosis 2021, 26, 152-162. [CrossRef] [PubMed]

63. Dimicoli, S.; Wei, Y.; Bueso-Ramos, C.; Yang, H.; Dinardo, C.; Jia, Y.; Zheng, H.; Fang, Z.; Nguyen, M.; Pierce, S.; et al. Overexpression of the toll-like receptor (TLR) signaling adaptor MYD88, but lack of genetic mutation, in myelodysplastic syndromes. PLoS ONE 2013, 8, e71120. [CrossRef] 
64. Sato, N.; Takahashi, N.; Suda, K.; Nakamura, M.; Yamaki, M.; Ninomiya, T.; Kobayashi, Y.; Takada, H.; Shibata, K.; Yamamoto, M.; et al. MyD88 but not TRIF is essential for osteoclastogenesis induced by lipopolysaccharide, diacyl lipopeptide, and IL-1alpha. J. Exp. Med. 2004, 200, 601-611. [CrossRef] [PubMed]

65. Kawao, N.; Yano, M.; Tamura, Y.; Okumoto, K.; Okada, K.; Kaji, H. Role of osteoclasts in heterotopic ossification enhanced by fibrodysplasia ossificans progressiva-related activin-like kinase 2 mutation in mice. J. Bone Miner. Metab. 2016, 34, 517-525. [CrossRef] [PubMed]

66. Yano, M.; Kawao, N.; Okumoto, K.; Tamura, Y.; Okada, K.; Kaji, H. Fibrodysplasia ossificans progressiva-related activated activin-like kinase signaling enhances osteoclast formation during heterotopic ossification in muscle tissues. J. Biol. Chem. 2014, 289, 16966-16977. [CrossRef] [PubMed]

67. El-Zayat, S.R.; Sibaii, H.; Mannaa, F.A. Toll-like receptors activation, signaling, and targeting: An overview. Bull. Natl. Res. Cent. 2019, 43, 187. [CrossRef]

68. Wesche, H.; Korherr, C.; Kracht, M.; Falk, W.; Resch, K.; Martin, M.U. The interleukin-1 receptor accessory protein (IL-1RAcP) is essential for IL-1-induced activation of interleukin-1 receptor-associated kinase (IRAK) and stress-activated protein kinases (SAP kinases). J. Biol. Chem. 1997, 272, 7727-7731. [CrossRef]

69. Hoffmann, E.; Ashouri, J.; Wolter, S.; Doerrie, A.; Dittrich-Breiholz, O.; Schneider, H.; Wagner, E.F.; Troppmair, J.; Mackman, N.; Kracht, M. Transcriptional regulation of EGR-1 by the interleukin-1-JNK-MKK7-c-Jun pathway. J. Biol. Chem. 2008, 283, 12120-12128. [CrossRef] 